\title{
A PERSONAL NOTE ON TRADEMARK AND UNFAIR COMPETITION LAW BEFORE THE LANHAM ACT
}

\author{
Milton HANDLER*
}

I was first exposed to antitrust and trademarks in the 1926 term of the United States Supreme Court, when I served as law clerk to Justice Stone. I had studied neither subject while at law school, a remarkable deficiency in my education having regard for the fact that both subjects were the centerpiece of my teaching, which extended for some forty-five years, and my practice over a period of some seventy years. The Court that term decided two trademark and unfair competition cases, with both opinions written by Justice Holmes. ${ }^{1}$ I doubt whether these opinions alone would have sufficiently kindled my interest to lead me to devote my entire adult life to these subjects. What aroused my interest was the conversation about trademarks between Justices Stone and Holmes at which I was present. Holmes's tribute to Frank Schechter's The Historical Foundations of the Law Relating to Trade-Marks ${ }^{2}$ induced me to immerse myself in this subject. I discovered that the first trademark case to be litigated in the federal courts was as late as 1844 , over 100 years before the enactment of the Lanham Act. ${ }^{3}$ The paucity of reported decisions made it possible for a neophyte to read all of the court opinions, which I did when I joined the Columbia faculty in 1927 . What I found was rather disconcerting; valuable brands of immense commercial magnetism were not accorded trademark status because of their etymological inferiority, despite the fact that they identified the source of the goods upon which they were affixed. Waterman Fountain Pens, Waltham Watches, and Kellogg Corn Flakes were trade names, not trademarks, and in theory (but not necessarily in fact) accorded limited and inadequate protection. At Columbia, my mentor, Professor Herman Oliphant, who pioneered the field with the first published casebook on trade regulation and who introduced the subject as a separate course in the law school curriculum, invited me to teach it notwithstanding my total unfamiliarity with the subject. He also encouraged me to put out a revised

Copyright $\mathbb{C} 1996$ by Law and Contemporary Problems

* Professor Emeritus, Columbia Law School; Senior Partner, Kaye, Scholer, Fierman, Hays \& Handler.

1. Beech-Nut Packing Co. v. P. Lorillard Co., 273 U.S. 629 (1926); Mosler Safe Co. v. Ely-Norris Safe Co., 273 U.S. 132 (1926).

2. Frank Schechter, The historical foundations of the law Relating to tradeMARKS (1925). I have referred to that conversation several times in prior writings. See Preface to MILTON HANDLER, BusinesS TORTS, CASES AND MATERIALS at xv (1972); Milton W. Handler, Are the State Antidilution Laws Compatible with the National Protection of Trademarks?, 75 TRADEMARK REP. 269, 270-71 (1985).

3. See SCHECHTER, supra note 2, at 134; Act of July 5, 1946, ch. 540, 60 Stat. 427 (codified as amended at 15 U.S.C. $\$ \$ 1057-1127$ (1994)). 
edition of his casebook. As antitrust was in the doldrums during the Coolidge and Hoover Administrations, I concentrated my research on trademarks and unfair competition.

Three decisions of Justice Holmes, two of which, as indicated, were handed down during the 1926 term, illustrated the primitive condition of these branches of the law and epitomized the need for reform.

In Waterman Co. v. Modern Pen Co. ${ }^{4}$ the Court affirmed a decree that restricted the defendant to using the name Arthur A. Waterman \& Co. instead of A. A. Waterman \& Co. In addition, the court required the words "not connected with the L. E. Waterman Co." to be juxtaposed in equally large and conspicuous letters when the permitted name was marked upon any part of the fountain pen sold by the defendant or upon boxes containing such pens, and whenever the name was used by way of advertisement or otherwise to denote any fountain pens made or sold by the defendant or to denote that it was the maker or seller of such pens. ${ }^{5}$

The Court thus permitted the use of the Waterman name as a means of identifying the source of defendant's product, relying upon the qualified use to protect the plaintiff's good will and to prevent consumer confusion. ${ }^{6}$ How many prospective purchasers of fountain pens knew that the initials of the manufacturer of the genuine pens were L. E. or that the initials of the maker of the spurious product were A. A. or that his first name was Arthur? Was this an effective way to prevent confusion of source or deception of the consumer?

In Beech-Nut Packing Co. v. P. Lorillard Co., ${ }^{7}$ the Beech-Nut Packing Company, owner of the Beech-Nut trademark used on ham, bacon, chewing gum, peanut butter, ginger ale, and other food products, sued to prevent the Lorillard Company from using "Beech-Nut" on chewing tobacco and cigarettes. ${ }^{8}$ Certiorari was granted to determine the extent to which, if at all, trademark protection is to be accorded against the use of the same trademark by a different company on an unrelated product. The case was argued by Charles Evans Hughes, then at the bar, for the plaintiff and by John W. Davis for the defendant. The issue was fully briefed and extensively argued by these two icons of the appellate bar. Everyone who was anyone in Washington attended the oral argument, and the Court's ruling was awaited with intense anticipation. Justice Holmes felt that the issue, which has perplexed the courts before and since the enactment of the Lanham Act, need not be decided because he concluded that the Lorillard Company, which traced its ownership of its Beech-Nut brand back to its usage before the American Tobacco

4. 235 U.S. 88 (1914).

5. Id. at 93 .

6. Justice Pitney in dissent described defendant's use of the Waterman name as a "sham and a fraudulent device." Id. at 98 (Pitney, J., dissenting).

7. 273 U.S. 629 (1926).

8. Id. at 630 . 
Company antitrust decree, had not expressly abandoned the mark. ${ }^{9}$ He ruled that "the mere lapse of time was not such that it could be said to have destroyed the right as matter of law." 10 Hence, he held that Lorillard could not be restrained from reusing a mark that had been dormant, but not abandoned.

In Mosler Safe Co. v. Ely-Norris Safe Co., ${ }^{11}$ the Mosler Company, claiming to be the only manufacturer of safes containing an explosion chamber for protection against burglary, sought an injunction to prevent the defendant from falsely representing that its safes contained an explosion chamber. ${ }^{12}$ The United States Court of Appeals for the Second Circuit, disagreeing with the Sixth Circuit's authoritative ruling in American Washboard Co. v. Saginaw Mfg. Co. ${ }^{13}$ reversed the district court, which had denied an injunction. ${ }^{14}$ Holmes found consistent with both the allegations in the complaint and the admission by defendant in its arguments, that there were other safes with explosion chambers besides the one manufactured by the plaintiff. ${ }^{15}$ Assuming the defendant's representation that its safe had an explosion chamber was false, the Court concluded "there is nothing to show that customers had they known the facts would have gone to the plaintiff rather than to other competitors in the

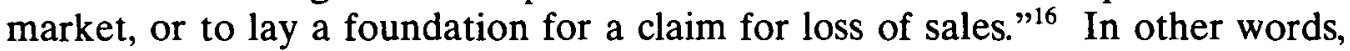
the Court sustained the rule of the Washboard case that a competitor cannot challenge the false advertising of a rival and, thus, claim injury flowing from the defendant's misrepresentation unless it is a monopoly. Since there are, thankfully, few monopolies, false advertising could not be restrained by competitors who truthfully marketed their products and who alone would have the incentive to bring suit.

Waterman indicated the need for an analysis and synthesis of the common law of trademarks, Mosler for adequate protection of tradesmen and consumers against false and misleading advertising, and Beech-Nut for a workable rationale for the protection of valuable brands beyond the precise boundaries of the area of their exploitation. It is curious that the founder of legal realism, who emphasized the overriding importance of experience, should have relied on precedent and a rigorous reading of the pleadings while ignoring the practical effects of his rulings.

9. Id. at 631-32.

10. Id. at 632 .

11. 273 U.S. 132 (1926).

12. Id.

13. 103 F. 281 (1900). The Washboard decision was by a Court consisting of Judges Taft, Lurton, and Day, all subsequent members of the Supreme Court.

14. Ely-Norris Safe Co. v. Mosler Safe Co., 7 F.2d 603 (2d Cir. 1925).

15. Mosler Safe, 273 U.S. at 134.

16. Id. 
I addressed these problems in a series of articles and in my participation in the First and Second Restatements of Torts. ${ }^{17}$ I also devoted a major part of my casebook ${ }^{18}$ to unfair competition and the various competitive torts.

In a 1930 article, Trade Marks and Trade Names-Analysis and Synthesis, ${ }^{19}$ Charles Pickett and I deplored the treatment accorded valuable brands that were not arbitrary, fictitious, or coined but rather descriptive. Those brands that were merely descriptive, together with personal names and geographical terms, were denominated trade names and, hence, were not registerable under the federal trademark legislation ${ }^{20}$ or protected under the common law of the states absent development of a secondary meaning. Apart from the fact that the term "trade name" was misleading and singularly inappropriate, since these marks were brand names and not the name of a business, the law treated such marks as second class citizens, only entitled to limited and inadequate protection. There were other anomalous aspects of the common law that deprived brands that were not technical trademarks of the protection that was essential to prevent deception of the public and to safeguard the brands' proprietors against the improper diversion of custom intended for them.

In my articles False and Misleading Advertising, ${ }^{21}$ Jurisdiction of the Federal Trade Commission Over False Advertising, ${ }^{22}$ and Unfair Competition, ${ }^{23}$ I dealt with the inadequacies of the common, statutory, and administrative law in curbing false and misleading advertising and in providing adequate protection against unfair competitive behavior. Corrective action on these important aspects of trademarks and unfair competition was taken by the Lanham Act, ${ }^{24}$ which permitted the registration of non-fanciful marks, personal names, and geographical terms on proof of their acquisition of secondary meaning. Once registered, they were to be accorded the same degree of judicial protection as technical marks.

The Lanham Act's most significant reform was its enactment of section $43(a),{ }^{25}$ whose original ambiguities were eliminated in subsequent revisions.

17. RESTATEMENT (FIRST) OF TORTS (1934); RESTATEMENT (SECOND) OF TORTS (Draft 1977) (never adopted by the ALI).

18. HANDLER, BUSINESS TORTS, supra note 2.

19. Milton Handler \& Charles Pickett, Trade Marks and Trade Names-Analysis and Synthesis (pts. 1 \& 2), 30 COLUM. L. REV. 168, 759 (1930).

20. The Trademark Act, ch. 592, 33 Stat. 724 (1905). Registration was permitted under the 1905 Act if such marks had been exclusively used for a period of 10 years before the enactment of the statute-a privilege of scant value to marks originating after 1905.

21. 39 YALE L.J. 22 (1929).

22. 31 COLUM. L. REV. 527 (1931).

23. 21 IOWA L. REV. 175 (1936).

24. ch. $540, \S 43,60$ Stat. 427 (1946) (codified as amended at 15 U.S.C. $\S 1125$ (1994)).

25. Section 43 (a) provides that

[a]ny person who, on or in connection with any goods or services, or any container for goods, uses in commerce any word, term, name, symbol, or device, or any combination thereof, or any false designation of origin, false or misleading description of fact, or false or misleading representation of fact, which $(\mathrm{A})$ is likely to cause confusion, or to cause mistake, or to deceive as to the affiliation, connection, or association of such person with another person, or as to the origin, sponsorship, or approval of his or her 
Section 43(a) has been the fountainhead of a vast body of law, which now constitutes a federal common law of trademarks and unfair competition. No longer is it necessary to attach a state common law claim in every trademark litigation against the possibility that the federally registered mark may be held substantively deficient. Originally, the courts, as is customary with new legislation, were stingy in their construction and application of the statute. But, in due course, reason prevailed, and a potent weapon was afforded in the unceasing war against improper business practices, some of which border on fraud and deception. Section 43(a), in my opinion, is the most significant advance wrought by the Lanham Act which, as other papers in this symposium indicate, has made other notable contributions in modernizing this important branch of the law. ${ }^{26}$

The First Restatement dealt directly with the Beech-Nut problem in a formulation designed to balance the interests of the parties where a mark is duplicated on other products, some related, some unrelated, or exploited in different geographical areas. $^{27}$ Judge Friendly, in the much-cited Polaroid

goods, services, or commercial activities by another person, or (B) in commercial advertising or promotion, misrepresents the nature, characteristics, qualities, or geographic origin of his or her or another person's goods, services, or commercial activities, shall be liable in a civil action by any person who believes that he or she is or is likely to be damaged by such act.

Id. $\S 43(\mathrm{a})$ (codified as amended at 15 U.S.C. $\S 1125(\mathrm{a})(1)(1994)$ ).

26. I had the privilege of drafting section 15 of the Wheeler-Lea amendments of the Federal Trade Commission Act, ch. 49, § 15, 52 Stat. 111, 116 (1938) (codified as amended at 15 U.S.C. $§ 55$ (1994)). For discussion, see Milton Handler, The Control of False Advertising Under the Wheeler-Lea Act, 6 LAW \& CONTEMP. ProBs. 91 (Winter 1939), as well as the New York legislation on false advertising, N.Y. Gen. Bus. Law, $\$ \S 350,350$ (a) (McKinney 1994). The offense of false advertising is defined as follows:

The term "false advertising" means advertising, including labeling, of a commodity, or of the kind, character, terms or conditions of any employment opportunity if such advertising is misleading in a material respect. In determining whether any advertising is misleading, there shall be taken into account (among other things) not only representations made by statement, word, design, device, sound or any combination thereof, but also the extent to which the advertising fails to reveal facts material in the light of such representations with respect to the commodity or employment to which the advertising relates under the conditions prescribed in said advertisement, or under such conditions as are customary or usual.

Id. § 350(a)(1) (McKinney Supp. 1996).

27. The First Restatement provided that

[i]n determining whether one's interest in a trade-mark or trade name is protected, under the rules stated in $\$ \$ 717$ and 730 , with reference to the goods, services or business in connection with which the actor uses his designation, the following factors are important: (a) the likelihood that the actor's goods, services or business will be mistaken for those of the other; (b) the likelihood that the other may expand his business so as to compete with the actor; (c) the extent to which the goods or services of the actor and those of the other have common purchasers or users; (d) the extent to which the goods or services of the actor and those of the other are marketed through the same channels; (e) the relation between the functions of the goods or services of the actor and those of the other; (f) the degree of distinctiveness of the trade-mark or trade name; (g) the degree of attention usually given to trade symbols in the purchase of goods or services of the actor and those of the other; (h) the length of time during which the actor has used the designation; (i) the intent of the actor in adopting and using the designation.

RESTATEMENT (FIRST) OF TORTS $\$ 731$ (1934) (discussed supra in text accompanying note 17). 
case ${ }^{28}$ improved on the Restatement formulation and, in his characteristically lucid style, defined the circumstances under which a mark would be protected when copied by other tradesmen and used on other products or in other geographical markets. ${ }^{29}$

With the changes instituted by the Lanham Act and the First Restatement, substantive trademark law was modernized and the serious deficiencies of prior law were overcome; however, there are three areas which today present serious problems in trademark and unfair competition law.

First, the courts have applied the Polaroid dictum in cases where the products are the same, contrary to the very opening words of the Friendly formulation. ${ }^{30}$ This unnecessarily complicates the determination of infringement and leads to a mathematical and unrealistic weighing of the many variables outlined by him. Several of these variables are singularly inapplicable where the products are the same. For example, if there is a likelihood of confusion and deception of the public, a registered mark, especially when it has become uncontestable, is entitled to protection under the statute whether it is a strong or a weak mark. I believe that infringement should continue to be determined as it was determined at common law, as intended under the two Restatements, ${ }^{31}$ and as required by the very wording of the Lanham Act. ${ }^{32}$ The misapplication of Polaroid weakens the protection to which the proprietor of a registered mark is statutorily entitled.

Second, the antidilution legislation moves in the direction of making any use of a trademark by another party taboo and thus unlawful. It proceeds on the theory of trespass rather than fraud. The concept of dilution is useful where the products are different. Where they are the same, a balanced law of trademarks and unfair competition should permit the continued use by others of trademarks that are not confusingly similar to the registered mark, even though they might

28. Polaroid Corp. v. Polarad Elecs. Corp., 287 F.2d 492 (2d Cir.), cert. denied, 368 U.S. 820 (1961).

29. Judge Friendly wrote that

[ $w$ ] here the products are different, the prior owner's chance of success is a function of many variables: the strength of his mark, the degree of similarity between the two marks, the proximity of the products, the likelihood that the prior owner will bridge the gap, actual confusion, and the reciprocal of the defendant's good faith in adopting its own mark, the quality of defendant's product, and the sophistication of the buyers. Even this extensive catalogue does not exhaust the possibilities-the court may have to take still other variables into account.

Id. at 495 (emphasis added).

30. See id.

31. Supra note 17.

32. Lanham Act, 15 U.S.C. $\S 1051-1127$ (1994). 
possibly be regarded as dilutive. ${ }^{33}$ We should not treat a registered trademark as analogically similar to a patent or copyright.

Third, recent Supreme Court decisions have held that trade-dress, product configuration, and color, like other trade symbols, are entitled to registration and enjoy the same substantive rights as other technical trademarks if they meet the statutory standards of fancifulness and distinctiveness. ${ }^{34}$ I would hope that the Court will not take the next step of satisfying the monopolistic aspirations of the owners of such indicia of source by preventing their imitation or copying by others, ignoring the teachings of Justices Brandeis and Holmes ${ }^{35}$ that latecomers may share in the good will of a product but not in the good will of the producer. Fair competition is enhanced by product simulation, while sharing in the producers' good will is unfair competition.

The Third Restatement of the Law of Unfair Competition ${ }^{36}$ is an extraordinary achievement. It is the authoritative compendium of our trademark and unfair competition jurisprudence. Its scholarship is of the highest order, and it represents the best thinking on the various topics it covers. It is an indispensable tool for all students, teachers, and practitioners. It is an appropriate climax to the fascinating developments in this corner of the law that have taken place since 1926 when I embarked on the personal voyage outlined in this essay.

33. See Milton W. Handler, Are the State Antidilution Laws Compatible with the National Protection of Trademarks?, 75 TRADEMARK REP. 269 (1985); see also Milton Handler, Letters to the Editor, 84 TRADEMARK REP. 101 (1994). Since the submission of this paper for publication, Congress has enacted as part of the Lanham Act, a section that prohibits the dilution of famous marks. 15 U.S.C. $\S 1125$ (c) (Supp. 1996). Notwithstanding this amendment, I still believe that the addition of a federal remedy against dilution is a mistake and that it will encourage additional litigation at a time when the courts are already overwhelmed by the volume of cases with which they deal.

34. Qualitex Co. v. Jacobson Prods. Co., 115 S.Ct. 1300 (1995); Two Pesos, Inc. v. Taco Cabana Inc., 505 U.S. 763 (1992).

35. Kellogg Co. v. National Biscuit Co., 305 U.S. 111, 122 (1938); Saxlehner v. Wagner, 216 U.S. 375, 380-81 (1910); Milton Handler, Product Simulation: A Right or a Wrong?, 64 COLUM. L. REV. 1178,1183 (1964).

36. RESTATEMENT (THIRD) OF UNFAIR COMPETITION (1995). 
